\title{
Lymphocyte Proliferation Activity MTT -Test of Ethanolic Extract of Pasak Bumi Root (Eurycoma longifolia Jack) on Induced 7,1 2-Dimethylbenz[A] Antracene (DMBA) Female Sprague Dawley Rat
}

\author{
Lily Noor Falah, Sapto Yuliani \\ Faculty of Pharmacy, Ahmad Dahlan University, Yogyakarta \\ Jl. Prof. Soepomo SH Janturan, Telp: (0274)379418, Yogyakarta, Indonesia
}

\begin{abstract}
Pasak bumi root (Eurycoma longifolia Jack) contains quasinoid. Quasinoid potentially has antitumor/anticancer, anti-parasitic, and immunostimulatory activity. The aim of this research was to study the lymphocyte proliferation activity MTT-test of ethanol extract of Eurycoma longifolia Jack root on induced by 7,12-dimethylbenz[a] antracene (DMBA) female Sprague Dawley rat. The test was done at 6 groups of 10 SD rat each. Each groups was administered orally with DMBA (Group I) dose of $20 \mathrm{mg} / \mathrm{kg}$ bw, corn oil (Group II), baseline (Group III), and ethanol extract of pasak bumi root dose 12.6; 25.2; and $50.4 \mathrm{mg} / \mathrm{kg}$ bw (Group IV,V,and $\mathrm{VI}$ ). Ethanol extract is given for 5 weeks. At the second week five rats were sacrificed to isolate the lymphocytes of spleen then rats are injected orally with DMBA 2 times a week for 5 weeks. At the eight until twenty fourth week all groups were just administered by aquades. Measurement of spleen relative weight and isolation of the lymphocyte spleen were done at second week and the last of experiment. Lymphocyte proliferation activity were measured by MTT-reduction method. Data were analyzed statistically by analyzes of variance (anova) continued by LSD test and Kruskall Wallis continued by Mann Whitney test. The result showed that limphocyte proliferation activity MTT of ethanol extract of $E$. longifolia root doses of 12.6; 25.2; and 50.4 $\mathrm{mg} / \mathrm{kg}$ bw for I4 days prior to DMBA-induced are $339.35 \pm 8.43 ; 61.20 \pm 6.27 ; 310.28 \pm 6.81$ and dose $50,4 \mathrm{mg} / \mathrm{kg}$ bw after DMBA-induced is $122.108 \pm 11.426$.
\end{abstract}

Keywords: $E$. longifolia root, spleen, lymphocyte cell, 7,12-Dimetilbenz (a) antracene (DMBA)

\section{INTRODUCTION}

Eurycoma longifolia Jack, known in Indonesia as Pasak bumi, has been widely used as traditional medicine for aphrodisiaca, antiplasmodium and anticancer (Ang et al., 2001). Pasak bumi herbal contains chemical compound such as eurycomalacton, lauricomalacton A, dehidroeuricomalacton, euricomanon, euricomanol, benzoqui-non, sterol, saponin, ester sterol fatty acid (Supriyadi et al., 2001), quasinoid, xanthin-6-on alkaloid, B-carbolin alkaloids, tiruccallan tipe triterpens, derivatif squallen, dan biphenilneolignans (Kuo et al., 2004). Activity of quasinoid as antitumor have been researched by Jiwanjinda et al (2003).

Breast cancer is an serious problem worldwide, increases up to $1-2 \%$ annually in many contries. Since year 2000 aproximately there are addional 1 million women wordwide suffered from this disease. The incidence of breast cancer in Indonesia women are ranked second after servical cancer (Tjindarbumi and Mangunkusumo, 2002). The therapy currently used including surgery, radiotherapy and chemotherapy were still unsatisfied as the side effect and non selectivity of radiotherapy and chemotherapy.

Development of tumor immunotherapies focuses on inducing autoimmune responses against tumor. One of parameters system immune activity is lymphocyte proliferation activity in spleen. Splenic lymphocyte proliferation is usually followed to evaluate a general effect on immune cells.

\footnotetext{
*Corresponding author e-mail: syuliani@yahoo.com
} 


\section{METHODS}

\section{Materials}

E. longifolia Jack root were obtained from Kalimantan, DMBA (7,12-dimetilbenz(a)antrasen) and RPMI medium were purchased from Sigma Chem. Other chemicals such as Phospat Buffered Saline (PBS), Sodium Dodecyl Sulphat (SDS), MTT(3-(4,5-dimethylethiazol-2-yl)-2,5-diphenyle tetrazolium bromide), $1 \mathrm{~N} \mathrm{NaOH}, 1 \mathrm{~N} \mathrm{HCl}$, Tris Buffered Ammonium Chloride (TBAH) were obtained from Integrated Research and Testing Laboratory, Gadjah Mada University.

\section{Extraction of $E$. Iongifolia root with ethanol}

Identification of the samples was done using standard botanical monographs. The ethanol extract was prepared by cold maceration of $250 \mathrm{~g}$ of E.longifolia root powder in $500 \mathrm{ml}$ of ethanol $70 \%$ allowed to stand overnight. The solution was then filtered, concentrated, dried in rotary evaporator and $63.5 \mathrm{~g}$ of thick dark brown extract residue stored in a refrigerator at $2-8^{\circ} \mathrm{C}$ for subsequent experiments.

\section{Animal treatment}

Female albino Sprague Dawley rats, weighing 100-180 g obtained from Gadjah Mada University breeding colony were used for the present investigations. The animals were maintained on standard rat feed supplied Comfeed. The test was done at 6 groups of $10 \mathrm{SD}$ rat each. Group I (cancer control) was given aquadest, group II was given corn oil, Group III was as baseline, Group IV,V, VI were given ethanol extract of pasak bumi root dose 12.6; 25.2; and $50.4 \mathrm{mg} / \mathrm{kg} \mathrm{bw}$. After 2 weeks, all groups except of group II and III, were administered orally by DMBA dose of $20 \mathrm{mg} / \mathrm{kg}$ bw 2 times a week for 5 weeks. Observation of tumor multiplicity and tumor incidence were done for sixteen weeks after the last DMBA administration. Measurement of spleen relative weight and isolation of the lymphocyte were done at second week and the end of experiment.

\section{Spleen Limphocyte Cell Isolation}

Rats were weighed and then sacrified by cervical dislocation. Spleens were removed by aseptic technique, weighed then mechanically dissociated into a single cell suspension in RPMI1640 medium and centrifuged at $1200 \mathrm{rpm}$, temperature $4^{\circ} \mathrm{C}$ for $10 \mathrm{~min}$. Centrifugation eliminates polymorphonuclear cells, erythrocytes and dead cells. The band containing the mononuclear cells was washed, pelleted and resuspended in Tris Buffered Ammonium Chloride (TBAH) and Phosphat Buffered Saline (PBS). This suspension of splenic mononuclear cells was defined as the splenocytes. Cells were counted in a haemocytometer. Limphocytes cell were cultured in $\mathrm{CO}_{2}$ incubator at $37^{\circ} \mathrm{C}$.

\section{MTT-reduction method}

MTT (3-(4,5-dimethylethiazol-2-yl)-2,5diphenyle tetrazolium bromide (Sigma) was dissolved in PBS at $5 \mathrm{mg} / \mathrm{ml}$ and filtered to sterilize and remove a small amount of insoluble residue present in some baches of MTT. Stock MTT solution $(10 \mu \mathrm{l})$ medium was added to all wells of an assay, and plates were incubated at $37^{\circ} \mathrm{C}$ for $4 \mathrm{~h}$. Sodium Dodecyl Sulffat (SDS) was added to all wells and thoroughly to dissolve the dark blue crystals. After a few minutes at room temperature to ensure that all crystals were dissolved, the plates were read on Elisa reader.

\section{Data Analyzes}

Calculation of relative spleen weigh:

$$
\begin{gathered}
\qquad \text { Relative spleen weigh }=\frac{\text { Spleen weigh }(g)}{\text { The last body weigh }(g)} \\
\text { Calculation of \% lymphocyte proliferation activity: } \\
\% \text { lymphocyte proliferation activity = Absorbancetreatment }- \text { Absorbancemedium } \quad \times 100 \%
\end{gathered}
$$

Average of Absorbance dmba group - Absorbance medium

All data are expressed as mean and standard deviation. Relative spleen weight prior and after DMBA- induced were analyzed statistically using one way ANOVA continued by LSD test. Percentage of limphocyte proliferation activity prior to and after DMBA-induced was analyzed using Kruskall Wallis test continued by Mann Whitney test. 


\section{RESULTS}

\section{Spleen weight}

Relative weight of the spleen was measured by analytical balance and expressed in gram. A significant increase in the weight of spleen was observed in ethanol extract of E. longifolia (group IV, V, and VI) when compared to other group (group I, II, III) prior to DMBA-induced.
Administration of E. longifolia dose $12.6 \mathrm{mg} / \mathrm{Kg}$ bw/day(group IV), dose $25.2 \mathrm{mg} / \mathrm{Kg}$ bw/day(group $\mathrm{V}$ ), dose $50.4 \mathrm{mg} / \mathrm{Kg}$ bw/day(group VI) for 2 week prior to DMBA-induced can significant increase relative spleen weight. There was not differ significantly among the E.longifolia groups. On the other hand the relative spleen weight of all groups after DMBA-induced were not differ significantly when compared each other (Table 1).

Table I. Relative spleen weigh (g) prior to and after DMBA-induced

\begin{tabular}{|c|c|c|c|c|}
\hline \multicolumn{2}{|r|}{ Group } & \multicolumn{2}{|c|}{ Before DMBA- induced } & \multirow{2}{*}{$\begin{array}{c}\text { After DMBA-induced } \\
0.0026 \pm 0.0005^{\mathrm{d}}\end{array}$} \\
\hline I. & DMBA (Group I) & 0.0080 & $\pm 0.0014 \mathrm{~b}$ & \\
\hline 2. & Corn Oil (group II) & 0.0074 & $\pm 0.0008^{b}$ & $0.0030 \pm 0.0003^{d}$ \\
\hline \multirow[t]{4}{*}{3.} & Baseline (group III) & 0.0083 & $\pm 0.0012^{b}$ & $0.0021 \pm 0.0008 \mathrm{~d}$ \\
\hline & dose $12,6 \mathrm{mg} / \mathrm{Kg}$ bw/day(group IV) & 0.0124 & $\pm 0.0015^{c}$ & $0.0036 \pm 0.0007 d$ \\
\hline & dose $25,2 \mathrm{mg} / \mathrm{Kg}$ bw/day (group V) & 0.0106 & $\pm 0.0022 c$ & $0.0049 \pm 0.0037 d$ \\
\hline & dose $50.4 \mathrm{mg} / \mathrm{Kg}$ bw/day(group VI) & 0.0108 & $\pm 0.0025^{c}$ & $0.0034 \pm 0.0007 d$ \\
\hline
\end{tabular}

Data are expressed as mean \pm SD ( $n=5$ rats per group). Groups with different superscript letters are significantly different at $P<0.05$ by analysis of variance continued by LSD test.

\section{Limphocyte Proliferation Activity}

Ethanol extract of E. longifolia root administration dose of $12.6 \mathrm{mg} / \mathrm{Kgbw} /$ day, 25.2 $\mathrm{mg} / \mathrm{kgbw} /$ day and $50.4 \mathrm{mg} / \mathrm{Kgbw} /$ day for 2 weeks (prior to DMBA-induced) can significant increase in the percentage of proliferation lymphocyte activity. Ethanol extract dose $12.6 \mathrm{mg} / \mathrm{Kgbw} /$ day was not differ significantly with dose 50.4 $\mathrm{mg} / \mathrm{Kgbw} /$ day. Ethanol extract E.longifolia root dose $25.2 \mathrm{mg} / \mathrm{kgbw} /$ day showed the lowest percentage of proliferation lymphocyte activity among the ethanol extract groups prior to DMBAinduced. Dose ethanol extract $50.4 \mathrm{mg} / \mathrm{Kgbw} /$ day after DMBA-induced showed the highest percentage of lymphocyte proliferation activity among ethanol extract groups. Increasing of percentage of lymphocyte proliferation activity dose $12.6 \mathrm{mg} / \mathrm{Kgbw} /$ day, $25.2 \mathrm{mg} / \mathrm{Kgbw} /$ day and corn oil group were not differ significantly when compared with baseline group (Table 2).

Table 2. Percentage of limphocyte proliferation activity in all groups prior to and after DMBA-induced

\begin{tabular}{ccc}
\hline Groups & $\begin{array}{c}\text { \% of limphocyte } \\
\text { proliferation activity } \\
\text { prior to DMBA- } \\
\text { induced }\end{array}$ & $\begin{array}{c}\text { \% of limphocyte } \\
\text { proliferation activity } \\
\text { after DMBA- induced }\end{array}$ \\
\hline DMBA & $100 \pm 0 \mathrm{a}$ & $100 \pm 0 \mathrm{a}$ \\
Corn Oil & $15.30 \pm 0.6 \mathrm{lb}$ & $51.928 \pm 19.265 \mathrm{e}$ \\
Base Line & $17.44 \pm 10.98 \mathrm{~b}$ & $38.689 \pm 10.885 \mathrm{e}$ \\
dose $12.6 \mathrm{mg} / \mathrm{Kgbw} /$ day & $339.35 \pm 8.43 \mathrm{c}$ & $61.825 \pm 10.554 \mathrm{e}$ \\
dose $25.2 \mathrm{mg} / \mathrm{Kgbw} /$ day & $61.20 \pm 6.27 \mathrm{~d}$ & $49.357 \pm 14.628 \mathrm{de}$ \\
dose $50.4 \mathrm{mg} / \mathrm{Kgbw} /$ day & $310.28 \pm 6.8 \mathrm{lbc}$ & $122.108 \pm 11.426 \mathrm{f}$
\end{tabular}

Data are expressed as mean \pm SD ( $n=5$ rats per group). Groups with different superscript letters are significantly different at $P<0.05$ by Kruskall Wallis continued by Mann Whytney test 
In this study, DMBA is used to induce the occurrence of cancer. According to Dandekar et al., (1986) Dimetilbenz (a) anthracene (DMBA), known as specific carcinogenic compounds. Carcinogenic activity of DMBA occurs because of the ability of DMBA metabolites (ultimate carcinogens) binds to DNA and cause somatic mutations that encourages rapid cell division (Miyata et al., 1999). The spleen is an organ found in virtually all vertebrate animals with important roles in regard to red blood cells and the immune system. Underwood (1999) explained that the white pulp is the biggest place that produce antibodies and to form the centrum germinativum when stimulated. Forming spleen white pulp lymphocytes is play a role in the immune system. Increased immune system will provide the protective effects of the body against foreign agents (antigens) that can damage cells.

Based on macroscopic observations show that not all rats edge taper-shaped organ. According to Brake (1997) exposure to the spleen by imunogen will evoke an immune activity of the spleen. In the event of increased immunity, spleen lymphocyte proliferation activity will increase so that the morphology of spleen size became larger. Normal spleen organ has the shape of the edge of the taper or crescent-like shape. Organs which have an enlarged spleen or swelling, the shape tends to blunt or rounded edges.

As shown at Table 1 that group IV, V, VI with ethanol extract of E. longifolia root administration prior to DMBA- induced differ significantly with groups non-ethanol extract of $E$. longifolia root administration (I, II, and III). Relative spleen weight was significantly higher in all doses of ethanol extract of E. longifolia root groups when compared with the control group. The result suggest that all of dose ethanol extract of E. longifolia root administration can increase relative spleen weigh of rats prior to DMBAinduced.

Limphocyte proliferation is activation phase of immune system. Increasing of spleen activity may indicate an increase of limphocyte proliferation causing an increase spleen in size. However, ethanol extract of E. longifolia can not affect to the relative spleen weight after DMBAinduced. This result was supported by Nurhaini (2009) that ethanol extract of E. longifolia can not affect histopathologic of spleen on rat induced by DMBA.

In this research determination of limphocyte proliferation activity using MTT method. MTT-test as alternative method to measurement of the cellular activity and proliferation. Indirectly counting using MTT assay is based on cell capablity in order to reduce MTT to insoluble water formazan (Fig. 1). Grey salt is corelation with a number of cell that can be detected by colorimetry (Shalini and Harriom, 2009). In this study determination of limphocyte proliferation activity was done at second week and end of the treatment. Persentage of the increasing limphocyte proliferation activity were presented in Table 2. Extract treatment group had a higher percentage proliferation activity compared with the CMC Na group (solvent control). These results indicate that administration of ethanol extract of $E$. longifolia Jack for 14 days can increase the lymphocyte proliferation activity significantly and have been able to act as imunogen. The results of this study shows compatibility with previous studies that exposure to the spleen by imunogen will evoke an immune activity so that the size of the spleen and spleen lymphocyte proliferation activity will increase. (Hargono, 2000; Akrom, 2004). From this study demonstrated that administration of ethanol extract of E. longifolia Jack for 14 days on animal Sprague Dawley female rats prior to DMBA-induced turns out to as immunostimulatory activity with a mechanism for increased lymphocyte proliferation. The results are consistent with data supporting the relative weights of the spleen that the extract dose group $12.6,25.2,50.4 \mathrm{mg} / \mathrm{kg}$ bw/day can increase the relative spleen weight significantly compared with the group that just getting $\mathrm{CMC} \mathrm{Na}$. 


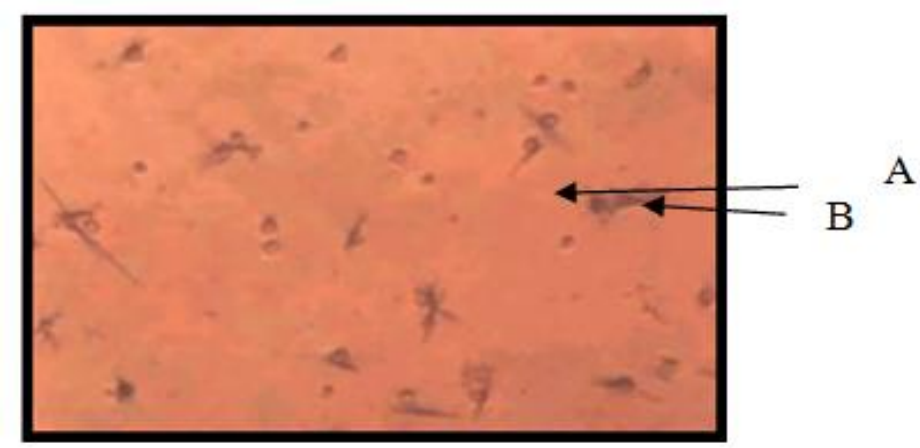

Figure I. Formazan formation in group administered by ethanol extract of E. longifolia Jack roots dose 50.4 $\mathrm{mg} / \mathrm{kg} /$ day for 14 days.

The results of lymphocyte proliferation activity in the 16th week after the last DMBA administration showed that DMBA can improve lymphocyte proliferation activity significantly when compared with solvent control (corn oil). This is probably caused that DMBA is a carcinogen which can be recognized by the immune system so that increased lymphocyte proliferation (Kresno, 2002). The limphocyte highest proliferation activity after administration of DMBA is shown in the dose of ethanol extract of $50.4 \mathrm{mg} / \mathrm{kg}$ bw/day. The biochemistry of the immunostimulatory activity by ethanol extract of E.longifolia roots may be caused that it serves as imunogen which kuasinoid able to be recognized by $\mathrm{T}$ cell receptor. Components of the ethanol extract of the roots can bind to $\mathrm{T}$ cell surface receptor through hydrogen bonding. Antigen binding receptor on the surface of $\mathrm{T}$ cells with interleukin 1 (IL-1) of the APC (Antigen Presenting Cell) may activate G-proteins which then produce phospholipase C. This enzyme hydrolyzes fosfatidil inositol bisphosphate (PIP2) into a reactive product diacylglycerol (DAG) and inositol triphosphate (IP3). The reaction took place in the plasma membrane. IP3 then stimulates the release of $\mathrm{Ca} 2+$ into the cytoplasm so that the concentration of $\mathrm{Ca} 2+$ increase. Increased $\mathrm{Ca} 2+$ plays an important role in stimulating action of the enzyme protein kinase $\mathrm{C}$ and 5-lipoxygenase. Protein kinase $\mathrm{C}$ production of interleukin 2 (IL2 ), IL-2 was then activates B cells and T cells to proliferate (Ikawati, 2006). Solving advanced through the DAG into arachidonic 5-lipoxygenase enhances the formation of cGMP. Increased cGMP resulted in increased activity of cGMP-dependent protein kinase that functions in the activation of DNA-dependent RNA polymerase, and synthesis of ribosomal (rRNA) and other RNA. RNA and protein synthesis causes B cells and T lymphocytes entering the phase of cleavage (Ikawati, 2006).

\section{CONCLUSSION}

Based on the results of this study can be concluded that limphocyte proliferation activity MTT of ethanol extract of E. longifolia root doses of $12.6 ; 25.2$; and $50.4 \mathrm{mg} / \mathrm{kg}$ bw for 14 days prior to DMBA-induced are $339.35 \pm 8.43 .61 .20 \pm 6.27$; $310.28 \pm 6.81$ and dose $50,4 \mathrm{mg} / \mathrm{kg}$ bw after DMBA-induced is $122.108 \pm 11.426$. Administration of ethanol extract of $E$. longifolian roots of dose $50.4 \mathrm{mg} / \mathrm{kg} /$ day can increase the activity of rat spleen lymphocyte proliferation in female SD rat that has been induced DMBA.

\section{REFERENCES}

Akrom, 2004, Cellular immune activity of Male Swiss Mice Infected Plasmodium berghei with The Ethanol Extract Phylantus niruri, Research Report, Fac. of Pharmacy, Ahmad Dahlan University, Yogyakarta.

Ang, H.H. and Ngai, T.H., 200I, Aphrodisiac evaluation in non-copulator male rats after chronic administration of Eurycoma longifolia, Fundamental \& Clinical Pharmacology, I5, 265-268.

Dandekar, S., Sukumar, S., Zaeld, H., Yuong, L., J.T. and Cardiff, R.D., 1986, Spesific Activation of The Cellular Harvey-ras Oncogen in DimethilbenzantraceneInduced Mouse Mammary Tumors, Molecular and Cellular Biology, 6(II), 4I044108.

Hargono, D, Winarno, M. W. and Werawati, A., 2000, Effect of Gynura Ngokilo Leaf Juice (Procumbers Lour Meer) on Mice againts 
Immune System Activity, Cermin Dunia Kedokteran, 127.

Ikawati, Z., 2006, Pengantar Farmakologi Molekuler, Yogyakarta, Gadjah Mada University Press

Jiwajinda, S., Santisopasari, V., Murakami, A., Kawanaka, M., Kawanaka, H., Gasquet, M., Elias, R., Balansard, G. and Ohigashi, H., 2002, Quassinoid from Eurycoma longifolia as Plant growth inhibitors, Phytochemistry, 58, 959-962.

Kresno, S.B., 200I, Imunologi: Diagnosis dan prosedur Laboratorium, Ed IV, Media, Jakarta.

Kuo, P.C., Damu, A.G., Lee, K.H. and Wu, T.S., 2003, Cytotoxic and Antimalarial betacarboline alkaloids from the roots of Eurycoma longifolia, J. Nat Product, Oct., 66(10), 1324.
Miyata, M., Kudo, G., Lee, Y., Yang, T.J., Gelboin, H.V. and Gonzalez, F.J., 1999, Targeted Disruption of the Microsomal Epoxide Hydrolase Gene, J. Biol. Chem., 274, 23963-23968.

Shalini, J. and Hariom, Y., 2009, Cell Proliferation Assay, Protocol Online.

Supriyadi, H.M. and Taryono, 200I, Pasak bumi (Eurycoma longifolia Jack) Plant Drug Indonesia, Use and Medicinal Properties, Pustaka Populer Obor, Jakarta.

Tjindarbumi, D. and Mangunkusumo, R., 2002, Cancer in Indonesia, Present and Future, Jpn J. Clin Oncol., 32(Supplement I), I7-2I.

Underwood, J.C.E., 1993, General and Systemic Pathology, $2^{\text {nd }} d .$, Vol II. Editor, Sarjadi. Jakarta, EGC. 